\title{
Ombudsman's experience in Psychosocial Care Centers for alcohol/drugs
}

\author{
A experiência da ouvidoria em um Centro de Atenção Psicossocial álcool/drogas \\ La experiencia de la audiencia en un Centro de Atención Psicosocial alcohol/drogas
}

\section{Marina Nolli Bittencourt', Diúlia Cristina Pantoja de Oliveira', Ruan Patrick de Oliveira Souza', José Luís da Cunha Pena', Paulo Victor das Neves Pantoja', Maria Odete Pereirall \\ ' Universidade Federal do Amapá. Macapá-AP, Brasil. \\ "Universidade Federal de Minas Gerais, Escola de Enfermagem. Belo Horizonte-MG, Brasil.}

\begin{abstract}
How to cite this article:
Bittencourt MN, Oliveira DCP, Souza RPO, Pena JLC, Pantoja PVN, Pereira MO. Ombudsman's experience in Psychosocial Care Centers for alcohol/drugs. Rev Bras Enferm [Internet]. 2018;71(Suppl 5):2287-94.

[Thematic Issue: Mental health] DOI: http://dx.doi.org/10.1590/0034-7167-2017-0924
\end{abstract}

Submission: 04-25-2018 Approval: 05-19-2018

\begin{abstract}
Objective: The objective of the study was to analyze criticisms, compliments and suggestions of users, family and workers, placed in an Ombudsman of a Centro de Atenção Psicossocial para Álcool e outras Drogas (Psychosocial Care Centers for Alcohol and Other Drugs- CAPS ad). Method: A study carried out in the CAPS ad of Macapá-AP from August to December 2016, through the thematic content analysis of the files deposited in the ombudsman, recently introduced in the service, containing criticisms, compliments and suggestions from users, family members, and CAPS ad. Results: It was observed the dissatisfaction with the infrastructure of the CAPS ad, and with the relationships built between users and professionals, in addition, suggestions were given of workshops, and improvement in the development of the Projeto Terapêutico Singular (freely translated as Unique Therapeutic Project). Final considerations: It is concluded that the multidisciplinary team needs to put in practice the real psychosocial care in the service, and that the management helps in the improvement of the service's place, and in the proposal of qualifications to this team.
\end{abstract}

Descriptors: Patient Advocacy; Substance Abuse Treatment Centers; Mental Health Services; Alcoholism; Substance-Related Disorders.

\section{RESUMO}

Objetivo: O objetivo do estudo foi analisar as críticas, elogios e sugestões dos usuários, familiares e trabalhadores, colocadas na Ouvidoria de um Centro de Atenção Psicossocial para Álcool e outras drogas (CAPS ad). Método: Estudo realizado no CAPS ad de Macapá-AP no período de agosto a dezembro de 2016, por meio da análise temática de conteúdo das fichas depositadas na ouvidoria, recém implantada no serviço, contendo críticas, elogios e sugestões de usuários, familiares, e trabalhadores do CAPS ad. Resultados: Observou-se a insatisfação com a infraestrutura do CAPS ad, e com as relações construídas entre usuários e profissionais, além disso, foram apresentadas sugestões de oficinas, e de melhora na construção do Projeto Terapêutico Singular. Considerações finais: Conclui-se sobre a necessidade de a equipe multidisciplinar colocar em prática a real atenção psicossocial no serviço, e que a gestão auxilie na melhora do local do serviço, e na proposição de capacitações à essa equipe. Descritores: Defesa do Paciente; Centros de Tratamento de Abuso de Substâncias; Serviços de Saúde Mental; Alcoolismo; Transtornos Relacionados ao uso de Substâncias.

\section{RESUMEN}

Objetivo: El objetivo del estudio fue analizar las críticas, elogios y sugerencias de los usuarios, familiares y trabajadores colocados en la Audiencia de un Centro de Atención Psicosocial para Alcohol y otras drogas (CAPS ad). Método: Estudio realizado en el CAPS ad de la ciudad Macapá, estado de Amapá desde el agosto hasta el diciembre 2016, a través del análisis temático de contenido de los archivos depositados en la audiencia, recién implantada en el servicio, conteniendo críticas, elogios y sugerencias de usuarios, familiares, y trabajadores del CAPS ad. Resultados: Se observó la insatisfacción con la infraestructura del CAPS ad, y con las relaciones construidas entre usuarios y profesionales. Además, se presentaron sugerencias de talleres, y de mejora en la construcción del proyecto terapéutico 
singular. Consideraciones finales: Se concluye sobre la necesidad de que el equipo multidisciplinario ponga en práctica la real atención psicosocial en el servicio, y que la gestión auxilie en la mejora del local del servicio, y en la proposición de capacitaciones a ese equipo. Descriptores: Defensa del Paciente; Centros de Tratamiento de Abuso de Sustancias; Servicios de Salud Mental; Alcoholismo; Trastornos Relacionados con Sustancias.

\section{CORRESPNDING AUTHOR Marina Nolli Bittencourt E-mail: marinanolli@hotmail.com}

\section{INTRODUCTION}

Not unlike other regions of the country, the Amapá state, even before the creation of a specific policy to care for users of alcohol and other drugs, in 2006, presented difficulties in establishing care measures for these individuals according to their specificities. Historically, the implementation of care for people who are characteristically placed in an exclusionary position, as in the case of drug users, whether legal or illegal is an arduous task for those who propose to perform it.

With Administrative Rule 226/2002, this arduous task became less complex, as the 226 Administrative Rule allowed the implementation of services for the care of people with alcohol and other drug needs, and with serious and persistent mental disorders: Psychosocial Care (CAPS), which are strategic components of open and community health of the Sistema Único de Saúde (Brazilian Unified Health System- SUS), being a reference point for treatment and resocialization of people suffering from mental disorders and recurrent needs for alcohol and other drugs. As a reception space, the exchange of experiences and daily dialogue is important in the construction of a process of interaction and communication between professionals and users, which dialogue with the uniqueness of the suffering subject and the process of Psychiatric Reform, in this way, a better efficiency in the quality of the service ${ }^{(1)}$, thus promoting its autonomy.

However, although they are services that encourage the autonomy of the subject and their citizenship, it is observed that often the relationships are vertical and unilateral, that is, the user only listens and does not have voice to express their opinion on their treatment and therapeutic project, together with the multidisciplinary health team ${ }^{(2)}$. In this sense, in 2003, the National Humanization Policy (PNH) was created to encourage communication between managers, workers and users to rethink the relationships between users and health professionals, allowing new perspectives and health practices that promote inclusion, respect and autonomy of the user and his/her family, who, based on suffering and sickness, seek the support of public health institutions to minimize such problems ${ }^{(3)}$.

The aim of the $\mathrm{PNH}$ in encouraging communication between managers and the individuals involved in a particular activity corroborates the meaning of Ombudsman, which originated with the sense of "Ombudsman" in Sweden, and in Brazil, after the dictatorship and the process redemocratization, gained strength as a tool that seeks to contribute to the process of building citizenship ${ }^{(4)}$.

Ombudsman in Health, as a managerial and assessment tool that was created in 2003 by Decree 4726, is strengthened by the National Humanization Policy, becoming a device for strategy of mediation of interests and communication between users, workers and managers, welcoming the manifestations of all the actors involved in health care, allowing for the return and referral of the problems presented ${ }^{(3)}$.

In this way, the ombudsman would be an important tool to encourage the protagonism of the user and his family, and to strengthen the communication between users, family members and professionals working in the CAPS ad, since the ombudsman, as a device that strengthens in the $\mathrm{PNH}$, allows, among other things, the inclusion and promotion of the autonomy of the users of health services and their family, which are one of the objectives of the psychosocial care performed in the CAPS. For this reason, and due to the lack of specific research on this subject, the relevance of this study is pointed out, and the positive example of results obtained, which will serve as a model for other CAPS ad in Brazil also to use this strategy that allows assessment of service and its practices, communication among users, family and multidisciplinary team, and encouragement to protagonism of the subjects.

\section{OBJECTIVE}

To analyze criticisms, compliments and suggestions of the users, family and workers of a CAPS ad placed in an ombudsman service recently implanted in the service.

\section{METHOD}

\section{Ethical aspects}

The study was approved by the Human Research Ethics Committee of the Universidade Federal do Amapá (UNIFAP). The research followed all the ethical precepts recommended by Resolution 466/12 of the CNS (Conselho Nacional de SaúdeNational Health Council)/MS, which addresses aspects related to human research.

\section{Type of study}

This is a descriptive research with a qualitative approach, in a critical-reflective perspective. The understanding of reality develops from critical analysis of processes, perceptions, structures and results by articulating the vision of social actors and the possibility of transforming their contexts ${ }^{(5)}$.

\section{Methodological procedures}

\section{Study setting}

The research took place in a CAPS ad, Espaço Acolher (Espaço Acolher is a multiprofessional clinic that values ethics and individuality, considering each of the situations presented in a respectful way. It offers services to children, teenagers and 
adults, in individual or family appointments. For the professionals of the space, client is the protagonist, being a task of the professional to help him/her in the process of discovery), located in the municipality of Macapá, capital of Amapá state, in the Central District. This choice is justified because it is the only state institution responsible for serving users of alcohol and other drugs, according to the model proposed by the Ministry of Health (MS- Ministério da Saúde).

\section{Data source}

The source of data was 31 files deposited in a wooden box sealed with the name "Ombudsman", which contained files with suggestions, criticism, and compliments of 22 users, 6 professionals, and 3 family members of the service.

\section{Collection and data organization}

Data collection was carried out from August to November 2016. In order to analyze assessments of the service through Ombudsman's service, the research was carried out in three stages: 1) orientation and preparation of researchers - undergraduate and graduate students; (Residency and Master's degree), for the implementation of ombudsman, 2) the implementation of ombudsman, and 3) analysis of assessments placed in the ombudsman box.

The first phase of the project took place in August 2016, at which point researchers went to the service for guidance of professionals and users about the ombudsman. Following the guidelines, and the authorization of the Coordination for Ombudsman's implementation, researchers set up a scale to be in the service, accompanying the deployment and participation of users, professionals and family members to guarantee the signing of the Informed Consent Term.

In the second phase, which took place in early September, the ombudsman was implanted in the service, consisting of a sealed wooden box, with the name "Ombudsman". Next to this box, there were left sheets of A4 paper with a place to check if it was a user, family or professional and the following description: "Leave your suggestions, compliments and criticism" plus a pen. In this way, users, family and professionals could put their impressions about the service offered by the institution researched. This box was placed on the receptionist's desk, which is located in the CAPS ad.

After the implementation, users were informed about this new communication device, and that, for research purposes, from September to December, those who used the ombudsman should sign the Informed Consent Form, which was at the side of the box, and handed it to researchers who were in the service, or to the receptionist.

The third phase occurred at the end of December. In this phase, researchers with the authorization of the Service Coordinator, removed the files deposited in the box called "Ombudsman". Thirty-three tokens were collected, including 22 user files, 6 service booklets, and 3 family files.

\section{Data analysis}

The content of the records was transcribed in its full, and a thematic content analysis method was carried out, which chronologically includes the steps of pre-analysis, material exploration, and treatment of the results obtained and interpretation ${ }^{(6)}$. The pre-analysis stage consisted in reading the material collected, in order to have contact with its structure, organization of the registration and context units, allowing orientation and direction in the analysis of impressions. In the exploration phase of the material, researchers carried out the distribution, classification scheme, and organization of quotes, phrases, tendencies and other determinations characteristic of the phenomenon investigated, dialoguing with part of the texts of the analysis, regrouping part of these in the themes encountered.

In the treatment of the results obtained and interpretation, the content underlying the contents was then decoded, articulating the objectives of the study with the trends, theoretical content and other determinations characteristic of the phenomena we were analyzing. At the end, the topics that emerged from the records were collected and analyzed using the thematic categorical content analysis method, which is characterized as a set of communication analysis techniques that uses systematic procedures and description objectives of message content ${ }^{(7)}$.

In order to better organize and direct the analysis of the results, it was decided to code the fiches with the words of the professionals of the multidisciplinary team of the CAPS by the letter " $\mathrm{P}$ ", the statements of the users of the service were codified with the letter " $U$ ", and the families were coded with the letter " $F$ ", followed by the identification number.

After the end of the analysis, an Assembly was marked in which the students who participated in the data collection presented the results for users and professionals.

\section{RESULTS}

The results obtained allowed grouping of the data, according to the theoretical framework adopted, into four categories: 1- Physical Structure, 2- Professional Interpersonal RelationshipUser, 3- Perception about the Dynamics of Service: Groups, Workshops and Appointments, 4-Perspectives of the User regarding the Unique Therapeutic Project; and three subcategories that originated in the second category (Professional Interpersonal Relationship- User), which are: a) Harmonic Relations, b) Conflictive Relations, and c) User's dissatisfaction with the Service.

\section{Physical Structure}

This first category is related to the infrastructure of the physical facilities of CAPS ad/Espaço Acolher. It is observed that, in general, people point out the precariousness of the physical structure.

[...] what is missing is a more proper physical structure to the service, lack of corrective and preventive maintenance of the central air. (P3)

Complaint: no receipt of funds, poor physical structure... (P1)

I would like to improve the quality of water and the reports on days with justice. (U1)

Negative points: infrastructure. (P2)

The difficulty of the service is in the lack of maintenance of the physical structure of the center. (P5) 
We are committed to making the best possible way for all activities but the financial resources is not much, but the desire to do the best for the patients is what makes us overcome the difficulties. (P4)

\section{Professional Interpersonal Relationship- User}

This second category refers to the relationship developed between professionals and users of CAPS ad/Espaço Acolher. The analysis of this category originated three subcategories: a) Harmonic Relationships b) Conflictive Relationships c) User's dissatisfaction with the Service.

\section{Harmonic Relations}

This subcategory discusses the interpersonal relationship between professionals and users of CAPS ad, we can observe positive points related to the service of professionals, service dynamics and the reception of users.

Lately our employees have been trying harder to please us ... keep it that way. (U3)

I have nothing to complain about the coordinator, psychiatrist, general practitioner, psychologist, nurses, and other house staff, well that's what I have to say. (U)

Great staff. CAPS provides great help for patients, thank you all. (U6)

For me, all the employees are to be congratulated in this entity, what is lacking to get better are public politicians recognize this process of recovery closely that benefits us, for that all the bodies had to meet and embrace this cause, we are all equal before the law and we need state support. (U10)

[...] CAPS ad is great that was created useful to help combat the addictions of society, starting with the host that is 1000 note! We already feel at home! So, congratulations to the receptionist who received us super good! And the whole team at the Center for the wonderful work of recovery. (U5)

\section{Conflictive Relations}

This subcategory presents cutbacks of conflictive relationships between professionals and users of CAPS ad, arising from the unpreparedness of professionals, disrespect and precarious reception.

That I have improvement is treatment here in this hospital. I liked the first appointments of the staff only lacked more competence to come at the right time, but taking this is all great, thanks. (U3)

This is bad, because people want to decide for me and not employees to charge me the time and they don't comply with $i t$, and they want to control my medication by making me a laboratory guinea pig. (U20)

The CAPS looks more like an insane asylum, than a home to support addicts, which don't treat patients with respect and care. (U11)

When talking about treatment for substance dependents, CAPS is a reference, but lately it is leaving to be desired, by the way that some employees are treating the patients, we need love. (U3)

\section{User's dissatisfaction with the Service}

This subcategory shows the user's dissatisfaction with some of the strategies adopted by the professionals in the treatment, and the lack of commitment and qualification, as can be observed in the statements below.

I have never seen a home, as the "acolher" name suspend patients more than 15 days and don't do the home visit. (U4)

It leaves much to be desired professionals who are trained to work with substance dependents and like what they do and of human beings. (U12)

That employees come to fulfill their working hours for the proper functioning of the institution, to expose the exercises made patient, thus making them feel useful and recognized for their abilities and above all there is an indication that they are qualified to exercise citizenship. (U17)

\section{Perception about the Dynamics of Service: Groups, Work-} shops and Appointments

This third category refers to the different perceptions regarding the forms of care developed in CAPS ad/Espaço Acolher.

[...] I feel welcomed. I think we should have more workshops. I feel that here we have the opportunity to recover and return to the society that is our place. Thanks to all the staff and friends who are helping me on this path. (U20)

To promote cultural event [support] for CAPS. More dedication. (U19)

Come back, music therapy. (U15)

Come back, CAPS movies. (U22)

\section{Perspectives of the User regarding the Unique Therapeutic Project}

This fourth category refers to the perspectives of users of CAPS ad/Espaço Acolher regarding the therapeutic plan. In general, users take part in the decisions of the therapeutic plan.

That patients could participate in the decisions of their treatment plan. (U6)

That they let patients decide their plan, this way it will never work. (U9)

The institution is cutting the therapeutic plan of patients, and with that we have already lost 05 patients who were killed and many of us went back to the drugs, that is, to the streets. (U8)

\section{DISCUSSION}

The present study allowed in general to observe important aspects of the functioning of CAPS ad, such as physical structure; professional interpersonal relationship and user; perception 
about the dynamics of care, and the user's perspectives on the Unique Therapeutic Project. The dissatisfaction with the infrastructure of the CAPS ad, and, at times, with the relations built between users and professionals, was observed in a general way; in relation to the dynamics of care, compliments and suggestions were presented, mainly suggestions of workshops, and improvement in the construction of the Unique Therapeutic Project.

The lack of physical structure of the CAPS ad, mainly related to the cooling of the rooms and spaces of individual and group service, was the most cited item in the present study. The Ministry of Health (MS) points out that CAPS must have a proper and appropriate space, prepared to meet their specific demand, capable of offering a structured and welcoming environment, with physical resources such as appointment rooms for group activities and living spaces, dining rooms to offer meals according to the length of stay of each patient in the CAPS and toilets ${ }^{(8)}$.

In addition, it is worth mentioning that a good physical infrastructure positively influences the quality of the CAPS ad service, from the host, to the choice of the most appropriate therapeutic plan for the patient, and its applicability. Therefore, in addition to what is proposed by the Ministry of Health ${ }^{(8)}$, the guidelines that shape the physical space of CAPS ad must take into account peculiarities as characteristics of the clientele that serves and the symptomatic manifestations of different mental disorders that affect such users and their families ${ }^{(9)}$.

In this way, the ideal physical structure for the CAPS is permeated by a pleasant environment that provides tranquility, comfort and that promotes the individuality of the individuals involved, as well as ensuring that employees perform their functions in the best and safe way, thus allowing there is an ambience in these places, guaranteeing the comfort to the users and workers, the privacy and individuality of the involved subjects and a space that promotes the encounter of subjectivities ${ }^{(10)}$.

The analysis of assessments related to the interpersonal relations between professionals of the multidisciplinary team and users of the CAPS ad pointed out that the relations are permeated by moments of harmony and conflicts. Harmonic relations were observed in the users' statements, which, through compliment, affirm that the professionals who work in the CAPS ad meet their needs, which shows that despite the physical difficulties of space, well-constructed relationships between the multidisciplinary team of the CAPS and the user, allow one of the roles of the CAPS to receive and promote a healthy bond is reached by some professionals engaged in this process of psychosocial rehabilitation.

This finding corroborates a study also carried out in the North region, in which most of the users highlighted the CAPS as the place that was better received within the Rede de Atenção Psicossocial (Psychosocial Care Network- RAPS), due to issues such as the relationship with the multidisciplinary team of the service ${ }^{(10)}$. As in the findings of this study, the users, family members and technicians of the service acknowledged that, despite the positive relationships built, professionals no longer do so because they do not have the conditions and resources to do $\mathrm{so}^{(11)}$, which were also pointed out by professionals and users of this study.

It is important to emphasize that these changes, especially in the interpersonal relationship between the multidisciplinary team of the CAPS and the user, are products resulting from the Brazilian Psychiatric Reform, since in Law 10.216/2001 there is a reformulation of the notions of space and therapeutic environment, proposing a dismantling of the mental health care and substitution for a new model of mental health care, CAPS, enabling new narratives, healthy individual and group therapeutic relationships that rescue the citizenship and human rights of the suffering person due to the use/abuse of psychoactive substances.

However, in spite of the existence of harmonic relations, it was also pointed out the conflictive relations between professionals and users, and the dissatisfaction related to the non-compliance of the schedules of the activities by some professionals, the disrespect to the user's autonomy, and the non-participation of the user in the construction of its Unique Therapeutic Project (PTS), in addition to the lack of empathy and bond in the process of hosting the multidisciplinary CAPS team.

It is believed that much of this dissatisfaction and these relational failures in the CAPS ad are a consequence of the very wear and tear of the multidisciplinary team of this service, since the demands that involve the context of CAPS ad consume time and energy of the professionals, because it is an intense clinic, which often leads to the feeling of absorption and wear of relationships ${ }^{(12)}$, which may have reflected in the dissatisfaction of the users who expressed themselves in the ombudsman.

In addition to this, it is important to report that this is the only CAPS ad in Amapá state that causes the demand and collection by users and other RAPS devices to be larger and increase the responsibility of these professionals, who they end up losing the careful practice that involves psychosocial care to meet these demands, in a service that still has several structural, organizational and financing failures that end up worsening. In addition to the fact that, because it is unique, it is a service that ends up not fulfilling its role as a specialized care device inserted in the territory, as recommended in the RAPS, causing inconvenience and impossibilities to those who cannot afford to go to the service.

In this sense, it is essential that the work of the CAPS be based on the idea of "clinic of the meeting" or "extended clinic", because when putting this practice into practice, professionals will be strengthening the delicacy of health work, through reflection and questioning about the work developed, as well as encouraging relations in which dialogue and listening are constantly strengthened during the construction of interpersonal relations ${ }^{(10)}$, making the multidisciplinary team of this service can look at relationships within the service and re- or even enhance the process of therapeutic relationship and therapeutic communication with the user and his/her family, in order to build more humanized, collective interventions that are in harmony with the Psychiatric Reform and that favor the strengthening of the bond and reintegration psychosocial support in daily life therapy.

By fostering therapeutic communication and interpersonal relationships, we will be facilitating the therapeutic process between a multidisciplinary team and a user in the field of Mental Health and Psychiatry ${ }^{(13)}$, in addition to facilitating the relationships that occur during the meetings with the relatives of these users, showing that such relationships have as characteristics the approximation with the subjects involved and the 
respect, the professional's greater attention to being to being cared for, commitment and qualified listening, which contributed to positive results in Mental Health Care, making the results of the meetings between these subjects is of great importance ${ }^{(10)}$.

Other points raised through the analysis of the users' speeches are related to the user's dissatisfaction with the offered service and the reception of the professionals to them, being considered by these as insufficient. This insufficiency of the reception provided ends up making the process of psychosocial rehabilitation and social reintegration of these subjects slower, because when the reception process is not performed effectively and effectively, the user encounters barriers in accessing the desired service, the which imposes on them the frequent return to health services, or even abandonment, since their needs were not met in the first moment ${ }^{(14)}$.

In this sense, the need for real commitment of professionals, from the first contact with the user and with their demands, takes place in the reception, at which point the professional captures a series of important information, until the ideal moment to create the ties with the employees and users of the service, in particular, what welcomes it.

The users also point out the absence of exhibitions of artistic and artisanal works of the users, built during workshops and therapeutic groups, and the little variety of workshops offered. Thus, as in other CAPS in Brazil, the CAPS ad in Macapá-AP also offers therapeutic workshops and promotes group activities so that its clients can exercise their individualities and promote their mental health, but despite the efforts of the multidisciplinary team of this service, it is not always possible to please everyone or offer a variety of workshops to be worked on the premises of CAPS, which leads to complaints from users. This problem ends up reflecting in the requests of new therapeutic workshops, and the return of others that no longer occur in the service, as identified in the data of the ombudsman.

However, it is essential that the multidisciplinary team of CAPS ad aware of this need pointed out by the users, since the elaboration of workshops and activities function as therapeutic strategies with the purpose of promoting the social reintegration of the subjects in society, causing them ${ }^{(4-9)}$, in addition to being a place where they can express their feelings, share their anguish, show their improvement and which points need more attention ${ }^{(15)}$, the which ultimately contributes to the appointments and the choice of the Unique Therapeutic Project, which in the CAPS ad of Macapá still presents itself as a challenge to be overcome.

Another factor to be pointed out is that the workshops help to reduce damages, as they involve strategies that can have an impact on consumption, promoting self-care, reducing vulnerabilities and situations of risk and reducing health problems caused by abusive use of alcohol and other drugs ${ }^{(16)}$, such as HIV infection, syphilis and hepatitis, malnutrition, hypertension, arrhythmias, problems with sleep, anxiety and depression.

Finally, we cannot forget that the Mental Health workshops are only considered therapeutic when they enable the users of the service a place of speech, expression and acceptance, because this is what reinforces their role of practices-producing services and they evolve psychosocial care ${ }^{(15)}$. Therefore, the desire of the users of this study to expose the works constructed in some workshops already point out the need for expression of these users, which should not only be within the service, but must happen beyond the walls of the CAPS, as well as the multidisciplinary team of the CAPS ad will be contributing to the practice of psychosocial rehabilitation of this service.

Regarding the user's perspectives on the PTS, it can be seen from the results that the users call for an effective participation in the construction of their PTS, expressing the desire to be together in their construction since involves questions about its own treatment, and its protagonism; in addition, they point to the deconstruction of therapeutic projects previously agreed with the team, and the consequences of this in the life of these subjects, so the importance of being built in collective.

Unfortunately, many professionals in these services are not yet prepared for the construction of the PTS; instead, there is a fragmentation of Mental Health care, characterized by individual and inflexible actions that do not promote the exchange of knowledge, the extended view on the user and the integrality of actions. Also in this context, we can observe the permanence of a biomedical model ${ }^{(15-19)}$.

However, the construction of PTS is one of the most important skills required of professionals or multidisciplinary teams that work in Mental Health services, because it is an tool that goes beyond the medical paradigm, in the sense of solving the needs of affected users beyond of the diagnostic criterion, through a set of therapeutic actions, resulting from the discussion and collective construction of a multidisciplinary team ${ }^{(1-20)}$, aiming at the clinical improvement and the reestablishment of fragile bonds ${ }^{(20)}$.

Another element to be discussed and that was observed in the study as a deficit is the client's role in the construction of the PTS. It is worth emphasizing that the construction of the PTS must be understood as a strategy that works together with the client, family and other social groups, being a constant process, integrated and with negotiations of actions aimed at satisfying needs, developing autonomy, protagonism and social inclusion ${ }^{(21-22)}$. Promoting this, it is possible to observe changes of a sustainable character, raising the independence of the subjects to health services through the activation of resources external to them ${ }^{(22)}$.

Finally, it is important to remember the importance of working with the multidisciplinary team of the CAPS for the construction of the PTS, since this tool also provides the professional with benefits for improving health care, since it acts as an arrangement and device from its construction, which allows the professional to reflect on their practice ${ }^{(21)}$. This action shows a way to improve care when taking into consideration the dimensions of Psychosocial Care, taking with it a critical attitude to favor the protagonists of their life and not to place them as mere observers of care.

\section{Study limitations}

This study has limitations, since it was carried out in a small Brazilian capital, located in a border region and with few social, economic and educational resources, which makes impossible the generalization of the data, besides having only one CAPS ad that serves all the population of the state.

However, these peculiar characteristics of Amapá state, which is not far from the characteristics of most Brazilian cities, especially the North and Northeast regions, points out the relevance of these data to the scientific community. 


\section{Contributions to health and public policy}

The results of this study pointed to the importance of the ombudsman as a further tool to promote citizenship and to build the contractual power of CAPS users, two essential aspects for the Psychosocial Rehabilitation of these subjects, which reinforces the contribution of this tool - the ombudsman, for the strengthening of the Brazilian Mental Health Policy and for the social control proposed by the Brazilian Unified Health System. Thus, an important tool to be implemented in the services that make up the Psychosocial Care Network.

\section{FINAL CONSIDERATIONS}

The results of this study allowed us to observe the efficiency of the ombudsman method in directly reaching the problems, from the perspective of the users and members of the multidisciplinary team of CAPS ad of Macapá. These perceptions demonstrate a series of harmonic and conflictive relations on the part of the investigated ones, where the user's dissatisfaction with the service is evident and punctuated, as well as the compliments of users to the CAPS ad multidisciplinary team.

We also emphasize that the therapeutic workshops offered by the CAPS ad in Macapá are still scarce, which ultimately provokes a complaint from the users, mainly for requesting diversity and new forms of therapeutic workshops, and the return of others that the service had. Another problem pointed out by the research subjects is the participation of the users in the construction of the Unique Therapeutic Project, described as non-existent, thus characterizing the non-effectiveness of this work tool by the multidisciplinary team in the service.

Therefore, it is observed the need of the multidisciplinary team of this service to construct a new meaning for Psychosocial Care dispensed to the users that it should go through the transformations coming from the Brazilian Psychiatric Reform, psychosocial rehabilitation, humanization and human rights. Besides being important that these professionals are also taken care of by the responsible coordination, since, often the dissatisfaction of the professionals allied to the lack of proper structure in the work, causes that also they become sick and fail to present their real role in the service.

\section{REFERENCES}

1. Brasil. Ministério da Saúde. Secretaria de Atenção à Saúde, Departamento de Atenção Básica. Política Nacional de Atenção Básica[Internet]. 2013[cited 2016 Dec 7]. Available from: http://189.28.128.100/dab/docs/portaldab/publicacoes/caderno_34.pdf

2. Cicera M, Brêda MZ, Henrique W, Damásio S, Cristina E, Moura DM. Interpersonal relationship between users and health professionals in psychosocial care. Cogitare Enferm[Internet]. 2016[cited 2016 Oct 27];21(3):1-9. Available from: http://revistas. ufpr.br/cogitare/article/view/46528/pdf

3. Brasil. Ministério da Saúde. Secretaria de Atenção à Saúde, Política Nacional de Humanização[Internet]. 2013[cited 2016 Dec 15]. Available from: http://bvsms.saude.gov.br/bvs/publicacoes/politica_nacional_humanizacao_pnh_folheto.pdf

4. Peixoto SF, Marsiglia RMG, Morrone LC. Atribuições de uma ouvidoria: opinião de usuários e funcionários. Saúde Soc[Internet]. 2013[cited 2016 Dec 15];22(3):785-94. Available from: https://www.scielosp.org/pdf/sausoc/2013.v22n3/785-794/pt

5. Minayo MCS, (Org.). O desafio do conhecimento: pesquisa qualitativa em saúde. 14 ed. São Paulo, SP: Hucitec; 2014.

6. Deslandes SF, Gomes R, Minayo MCS. Pesquisa social: teoria, método e criatividade. 20ª ed. Petrópolis: Vozes; 2002.

7. Bardin L. Análise de Conteúdo. São Paulo: Edições 70; 2011.

8. Brasil. Ministério da Saúde. Secretaria de Atenção à Saúde, Departamento de Ações Programáticas Estratégicas. Saúde mental no SUS: os centros de atenção psicossocial. Brasília, DF: 2004; 86.

9. Kantorski LP, Coimbra VCC, Silva ENF, Guedes AC, Cortes JM, Santos F. Qualitative assessment of the environment in a Psychosocial Care Center. Ciênc Saúde Colet[Internet]. 2011[cited 2017 Feb 15];6(4):2059-66. Available from: http://www.scielo.br/pdf/csc/ v16n4/v16n4a05.pdf

10. Camatta MW, Nasi C, Adamoli AN, Kantorski LP, Schneider JF. Evaluation of a Psychosocial Care Center: the view of the family. Ciênc Saúde Colet[Internet]. 2011[cited 2017 Mar 08];16(11):4405-14. Available from: http://www.scielo.br/pdf/csc/v16n11/ a13v16n11.pdf

11. Cardoso MRO, Oliveira PTR, Piani PPF. Care practices in mental health in the voice of users from a Psychosocial Care Center of the State of Pará. Saúde Debate[Internet]. 2016[cited 2017 Mar 24];6(40):86-99. Available from: http://www.scielo.br/pdf/sdeb/ v40n109/0103-1104-sdeb-40-109-00086.pdf

12. Silva DLS, Knobloch F. The team as a place of education: the continuing education in a psychosocial attention center of alcohol and other drugs. Interface[Internet]. 2016[cited 2017 Mar 24];20(57):325-35. Available from: http://www.scielosp.org/scielo. php?script $=$ sci_arttext $\& a m p \% 5 C n p i d=S 1414-32832016000200325$

13. Stefanelli MC, Fukuda IMK, Arantes EC. Enfermagem psiquiátrica em suas dimensões assistenciais. São Paulo: Manole; 2008.

14. Clementino FDS, Miranda FAN, Martiniano CS, Marcolino EDC, Pessoa Jr JM, Dias JDA. Assessment of organizational structure of centers for psychosocial care in the City of Campina Grande, Paraíba State. Rev Bras Ciênc Saúde[Internet]. 2016 [cited 2017 Mar 24];20(4):261-8. Available from: http://periodicos.ufpb.br/ojs/index.php/rbcs/article/view/25340/16073

15. Azevedo DMD, Miranda FAND. Therapeutic workshops as means of psychosocial rehabilitation: perception of family. Esc Anna Nery 
Rev Enferm[Internet]. 2011[cited 2017 Mar 24];15(2):339-45. Available from: http://www.scielo.br/pdf/ean/v15n2/v15n2a17.pdf

16. Moura FG, Santos JE. Care delivery to users at a psychosocial care center for alcohol and other drugs: a collective subject perspective. SMAD Rev Eletrôn Saúde Ment Alcool Drog[Internet]. 2011[cited 2017 Mar 24];7(3):126-32. Available from: https://pdfs.semanticscholar. org/b43f/b65ea4fa61d9a45e24992f9b355afb315ea6.pdf?_ga = 2.80439827.58217614.1530573789-1526278839.1530573789

17. Jardim VMR, Cartana MHF, Kantorski LP, Quevedo ALA. Evaluation of mental health policy based on Psychosocial Care Center Therapeutic projects [Internet]. 2009[cited 2017 Mar 24];04(06):241-8. Available from: http://www.redalyc.org/articulo. oa?id $=71411706006$

18. Merhy EE. Governing tensions in the health action as a permanent challenge of some managerial strategies. Ciênc Saúde Colet[Internet]. 1999[cited 2017 Mar 24];4(2):305-14. Available from: http://www.scielo.br/pdf/csc/v4n2/7114.pdf

19. Nunes M, Torrenté M, Ottoni V, Moraes Neto V, Santana M. [The dynamics of mental health care: health professionals' signs, meanings, and practices in a Center for Psychosocial Care in Salvador, Bahia State, Brazil]. Cad Saúde Pública[Internet]. 2008[cited 2017 Mar 24];24(1):188-96. Available from: http://www.scielo.br/pdf/csp/v24n1/18.pdf Portuguese

20. Mororó MEML. Cartografy, challenges and potencials in construction projects in therapeutic Center of Attention Psychosocial CAPS III[Dissertação]. Escola de Enfermagem da Universidade de São Paulo; 2010.

21. Vasconcelos MGF, Jorge MSB, Catrib AMF, Bezerra IC, Franco TB. [Therapeutic design in Mental Health: practices and procedures in dimensions constituents of psychosocial care]. Interface[Internet]. 2016[cited 2017 Mar 24];20(57):313-23. Available from: http://www.scielo.br/pdf/icse/v20n57/1807-5762-icse-20-57-0313.pdf Portuguese

22. Boccardo ACS, Zane FC, Rodrigues S, Mângia EF. The singular therapeutic project as a strategy of organization for care in mental health services. Rev Ter Ocup Univ[Internet]. 2011[cited 2017 Mar 24];22(1):85-92. Available from: http://sites.multiweb.ufsm. br/residencia/images/Materiais/PTS.pdf 